\section{EFFECT OF PH ON ADSORPTION OF ORGANIC ACIDS AND PHENOLIC COMPOUNDS BY AMBERLITE IRA 67 RESIN}

\author{
Haslaniza Hashima*, Wan Yaacob Wan Ahmadb, Saiful Irwan \\ Zubairia,b, Mohamad Yusof Maskata
}

aCentre for Biotechnology and Functional Food, Faculty of Science and Technology, Universiti Kebangsaan Malaysia, 43600 UKM Bangi, Selangor, Malaysia

bCentre for Advanced Materials and Renewable Resources, Faculty of Science and Technology, Universiti Kebangsaan Malaysia, 43600 UKM Bangi, Selangor, Malaysia
Article history

Received

29 March 2018

Received in revised form

9 August 2018

Accepted

1 September 2018

Published online

15 December 2018

*Corresponding author haslaniza@ukm.edu.my

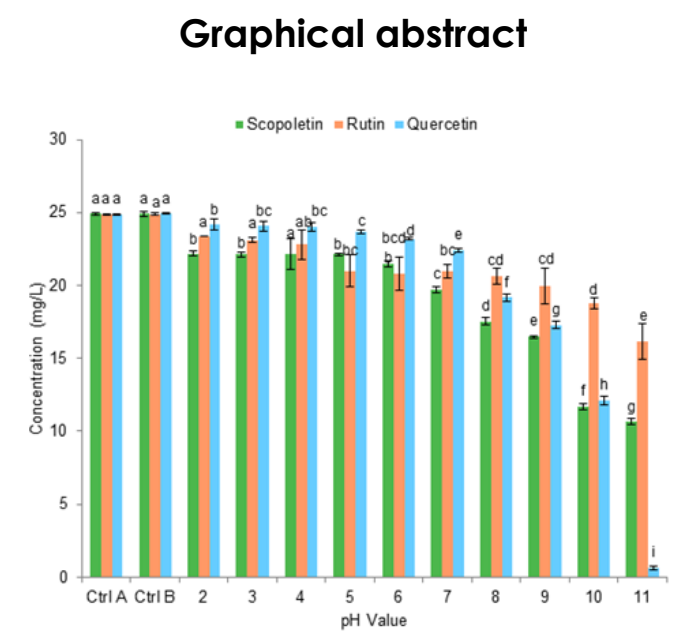

Graphical abstract

$\mathrm{pH}$ Value

\begin{abstract}
Adsorption of model solution containing organic acids (octanoic and hexanoic acid) and phenolic compounds (rutin, scopoletin and quercetin) on a weak base anion exchange Amberlite IRA 67 resin was studied in a model system. This research was carried out to understand the effect of $\mathrm{pH}$ on single and multicompounds studied for its further use in actual system (fruit system). It was shown that the $\mathrm{pH}$ dependence of adsorption capacity of weak base anion exchange Amberlite IRA 67 resin had similar increasing trend on organic acids (hexanoic and octanoic acid) and phenolic compounds (rutin, scopoletin and quercetin) studied as $\mathrm{pH}$ values increased. In single solution of each phenolic compound, it was observed that total phenolic content (TPC) and antioxidant activity (FRAP and DPPH) gave highest values closer to neutral $\mathrm{pH}$ regime. The $\mathrm{pH}$ dependence of adsorption capacity in multicompounds solution also showed similar trend for organic acid compounds. Similar trend was also found in multicompounds solution of phenolic compounds in total phenolic content (TPC) and antioxidant activity (FRAP and DPPH). The findings obtained in this study will help to gain better understanding of the complex mechanisms of ion exchange resin and adsorption process involving multicompounds system.
\end{abstract}

Keywords: Adsorption, ion exchange resin, hexanoic acid, octanoic acid, phenolic compounds, $\mathrm{pH}$

\begin{abstract}
Abstrak
Penjerapan larutan model iaitu asid organik (asid oktanoik dan asid heksanoik) dan sebatian fenolik (rutin, skopoletin dan kuersetin) pada resin penukar ion bes lemah Amberlite IRA 67 dikaji di dalam sistem model. Kajian ini dijalankan untuk memahami kesan $\mathrm{pH}$ pada larutan sebatian tunggal dan sebatian multi untuk diaplikasikan di dalam sistem sebenar (sistem buah). Hasil kajian ini menunjukkan kebergantungan $\mathrm{pH}$ pada kapasiti penjerapan resin penukar ion bes lemah Amberlite IRA 67 mempunyai tren yang meningkat pada asid organik asid organik (asid oktanoik dan asid heksanoik) dan sebatian fenolik (rutin, skopoletin dan kuersetin) apabila nilai $\mathrm{pH}$ ditingkatkan. Dalam larutan tunggal bagi setiap sebatian fenolik,pemerhatian menunjukkan kandungan fenolik jumlah (TPC) dan aktiviti antioksida (FRAP dan DPPH) memberikan nilai bacaan tertinggi menghampiri $\mathrm{pH}$ neutral. Kebergantungan $\mathrm{pH}$ pada kapasiti penjerapan di
\end{abstract}


dalam larutan sebatian multi juga menunjukkan tren yang sama untuk sebatian asid organik. Tren yang sama turut diperhatikan pada larutan sebatian multi bagi sebatian fenolik (TPC) dan aktiviti antioksida (FRAP dan DPPH). Penemuan yang diperolehi daripada kajian ini akan membantu untuk lebih memahami mekanisme yang kompleks pada resin penukar ion dan proses penjerapan yang melibatkan sistem sebatian multi.

Kata kunci: Penjerapan, resin penukar ion, asid heksanoik, asid oktanoik, sebatian fenolik, $\mathrm{pH}$

(c) 2019 Penerbit UTM Press. All rights reserved

\subsection{INTRODUCTION}

Morinda citrifolia L. is a Rubiaceous plant widely distributed in many tropical areas [1]. Commonly called noni, it is used traditionally to treat a broad range of diseases reportedly for over 2000 years [2]. About 160 phytochemical compounds have already been identified in M. citrifolia plant, and the major micronutrients are phenolic compounds, organic acids and alkaloids [3]. The unpleasant odor of $M$. citrifolia extract was reported to have been contributed by medium chain fatty acids such as decanoic, hexanoic and octanoic acid [4]. Deacidifcation of $M$. citrifolia juice has been attempted by previous researchers using activated charcoal [4]), calcium carbonate $[5,6]$ and fermentation [7]. However, although the unpleasant odor was reduced, antioxidant activities were also reduced. Base anion exchange resin (Amberlite IRA 67) showed promising potential to be used for deacidification while it also gave minimal reduction on antioxidant content [8].

Recently, more attention has been focused on the role of natural antioxidants, in particular, phenolic compounds, which may act both by reducing the content of toxic compounds in foods and by supplying the human body with exogenous antioxidants [9]. Scopoletin is a characteristic phytochemicals in M. citrifolia fruits, while rutin and quercetin are bioactive flavonoids [10] commonly found in $M$. citrifolia juice as reported by previous researchers $[2,10,11,12,13,14,15,16]$. Due to the beneficial role of antioxidants, it is important that deacidification did not reduce the antioxidant activity. The $\mathrm{pH}$ of the aqueous solution is an important controlling parameter in any adsorption process, particularly in the adsorption capacity [17]. The $\mathrm{pH}$ value can affect the process by affecting the surface change of adsorbent, the degree of ionization and speciation of adsorbate during adsorption [18]. In this model system studied, the solution of organic acids and phenolic compounds were used to stimulate actual noni juice using identical values of $\mathrm{pH}$. The desired condition when adsorption capacity of organic acids is at the lowest while phenolic compound is at the highest can be achieved by manipulating $\mathrm{pH}$ of the solution.

\subsection{METHODOLOGY}

\subsection{Materials}

Weak base anion exchanger Amberlite IRA 67 (food grade) (Table 1) and standard of octanoic acid, hexanoic acid, rutin, scopoletin and quercetin were purchased from Sigma Aldrich Corporation (St. Lovis, MO, USA). Methanol (purity $>99.9 \%$ ), HPLC grade was purchased from Fisher Scientific (New Jersey, USA). The molecular structure of organic acids and phenolic compounds were shown in Figure 1.

Table 1 Chemical and physical properties of resin

\begin{tabular}{ll}
\hline & Amberlite IRA 67 \\
\hline Chemical matrix & Crosslinked acrylic gel \\
Functional group & Tertiary amine \\
& $\geq 1.60$ (FB form) \\
$\begin{array}{l}\text { Total exchange capacity } \\
\text { (eq/L) }\end{array}$ & Translucent white spherical \\
Physical form & beads \\
Particle size (mm) & $0.50-0.75$ \\
Producer & Sigma Aldrich, Germany \\
\hline Source: Rohm and $\mathrm{Hads}$ &
\end{tabular}

a) Organic acids

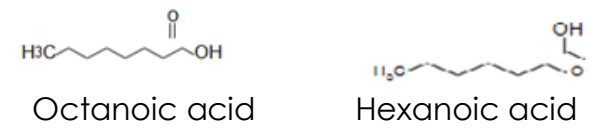

b) Phenolic compounds

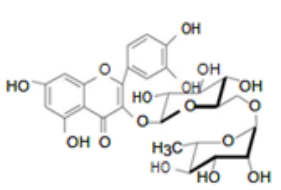

Rutin

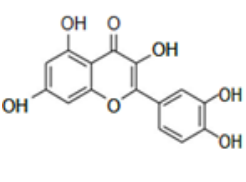

Quercetin

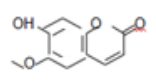

Scopoletin
Figure 1 Molecular structure of organic acids and phenolic compounds 


\subsection{Adsorption Studies of Organic Acids and Phenolic Compounds}

The adsorption studies were carried out in Erlenmeyer flasks where $0.1 \mathrm{~g}$ of the dry anion exchanger and $0.02 \mathrm{~L}$ of each samples which were octanoic acid (250 mg/L), hexanoic acid (100 mg/L), rutin (25 $\mathrm{mg} / \mathrm{L})$, scopoletin $(25 \mathrm{mg} / \mathrm{L})$, and quercetin $(25$ $\mathrm{mg} / \mathrm{L}$ ), were added without $\mathrm{pH}$ adjustment. The flasks were agitated in the orbital shaker (WiseCube, Daihan Scientific, Korea) at a constant speed of 120 rpm for $180 \mathrm{~min}$ to achieve equilibrium. Each of the organic acids after equilibrium adsorption was measured using a Gas Chromatography (Agilent, Model HP6890, USA) equipped with Flame Ion Detector (FID). Meanwhile, each of the phenolic compounds was measured using High Perfomance Liquid Chromatography (HPLC). The amount of organic acids and phenolic compounds adsorbed at equilibrium, qe $(\mathrm{mg} / \mathrm{g})$, were calculated as the Equation 1 below:

$$
q_{e}=\frac{\mathrm{C}_{\mathrm{o}}-\mathrm{C}_{\mathrm{e}}}{\mathrm{w}} \times \mathrm{V}
$$

Where $\mathrm{C}_{0}$ and $\mathrm{C}_{e}$ are the concentrations of the each organic acids and phenolic compounds at the beginning and in the equilibrium, respectively (mg/L); $V$ is the volume of the solution (L); $W$ is the mass of the dry anion exchanger (g).

\section{3 pH Determination}

$\mathrm{pH}$ determination were carried out on all samples using (Model PB-10, Sartorius Basic Meter, Germany). The $\mathrm{pH}$ meter was calibrated using $\mathrm{pH} 4.0$ and 7.0 buffer. The solution of each compound was stirred before measuring the $\mathrm{pH}$ values. The $\mathrm{pH}$ was adjusted using dilute $\mathrm{NaOH}$ and $\mathrm{HCl}$ solutions. The reading was taken at room temperature.

\subsection{UV-Vis Spectroscopy}

UV-Vis absorption spectra of rutin, scopoletin and quercetin were recorded on a spectrophotometer (Shimadzu, UV-2450, Japan) in $4.5 \mathrm{~mm}$ based on wavelength of maximum absorbance. The wavelength for rutin was $350 \mathrm{~nm}$ and quercetin 370 $\mathrm{nm}$ [19], and scopoletin was at $280 \mathrm{~nm}$ [20]. Samples were put in quartz cuvette $(1 \mathrm{~cm} \times 1 \mathrm{~cm} \times 4.5 \mathrm{~cm})$ at reading were taken at room temperature.

\subsection{Determination of Organic Acids using GC}

Organic acids (octanoic acid and hexanoic acid) were extracted using Gas Chromatography for 10 min according to the previous study done by [21] with some modification. A $1 \mu l$ sample was inserted immediately using microliter syringe (Hamilton, Model \#701, USA) into the injection port of a Gas Chromatography Mass Spectrometry (Agilent, Model
HP6890, USA) equipped with Flame Ion Detector (FID) and split injector using an inlet SPME $0.75 \mathrm{~mm}$ (Supelco). A capillary column HP-5 (30m x 0.25 i.d., $0.25 \mu \mathrm{m}$ film thickness, J\&W Scientific Pte Ltd, USA) was used.

Nitrogen $\left(\mathrm{N}_{2}\right)$ was used as carrier gas. Oven temperature was programmed according to the method of [22] with some modifications. Initial temperature was $80^{\circ} \mathrm{C}$ for 2 min before raised to $80^{\circ} \mathrm{C}$ at $20^{\circ} \mathrm{C} / \mathrm{min}$ for $1 \mathrm{~min}$, then heated to $100^{\circ} \mathrm{C}$ at $20^{\circ} \mathrm{C} / \mathrm{min}$ for $1 \mathrm{~min}$. When it reached $100^{\circ} \mathrm{C}$, the temperature finally raised to $250^{\circ} \mathrm{C}$ at $30^{\circ} \mathrm{C} / \mathrm{min}$ and held for $1 \mathrm{~min}$. The gas flow rate was $40 \mathrm{~cm} / \mathrm{s}$. The total time for separation for each samples were 10 min. Percentage of peak area were determined by comparing the peak retention time for the standard of octanoic acid with the peak retention time for deacidified samples. The analysis was expressed as concentration (mg/L) obtained from the software.

\subsection{Determination of Ferric Reducing Assay (FRAP)}

FRAP assay was conducted according to the method of [23] with some modification. FRAP reagent was prepared from acetate buffer $(0.3 \mathrm{M}, \mathrm{pH} 3.6), 10$ mM TPTZ solution in $0.04 \mathrm{M} \mathrm{HCl}$ and $0.02 \mathrm{M}$ iron (III) chloride solution in proportion of 10:1:1 ( $/ \mathrm{v} / \mathrm{v})$ respectively. The FRAP reagent was prepared fresh daily and incubated at $37^{\circ} \mathrm{C}$ in waterbath prior to use. A total of $50 \mu \mathrm{l}$ samples juice were added to $1.5 \mathrm{ml}$ of the FRAP reagent and mixed well. The absorbance was measured at $593 \mathrm{~nm}$ using spectrophotometer (Spectronic 200, Madison, WI USA) after 4 min time. Samples were measured in three replications. A standard curve was prepared using a series of standard solution of iron (II) sulphate $(200-1000 \mu \mathrm{M})$. The results were expressed as $\mu \mathrm{mol} /$ $\mathrm{g}$ fresh weight (FW) sample.

\subsection{Determination of Free Radical Scavenging using DPPH Method}

The antioxidant activity of all juices were evaluated through free radical scavenging effect on 1,1diphenyl-2-picrylhydrazyl (DPPH) radical [24]. Two ml of $0.1 \mathrm{mM}$ DPPH methanolic solution was added into $200 \mu \mathrm{l}$ of sample juice and $0.8 \mathrm{ml}$ methanol. The mixture was prepared by mixing $2 \mathrm{ml}$ of DPPH and 1 $\mathrm{ml}$ methanol. The absorbance was measured at 517 $\mathrm{nm}$ using spectrophotometer. Samples were measured in three replications. Percentage of free radical scavenging activity was calculated based on the formula below:

\% inhibition of DPPH $=$ [Abs control - Abs sample $/$ Abs control] $\times 100$.

\subsection{Determination of Total Phenolic Content}

Total phenolic content of noni juice was determined using Folin-Ciocalteau reagents as described by [25]. Samples were inserted into different test tube and 
mixed thoroughly with $5 \mathrm{ml}$ Folin-Ciocalteau reagent (previously pre-dilute 10 times with distilled water). After $5 \mathrm{~min}, 4 \mathrm{ml}$ of $7.5 \%$ sodium carbonate ( $\mathrm{Na} 2 \mathrm{CO} 3$ ) was added and allowed to react for 2 hrs at room temperature. The absorbance was measured at 765 $\mathrm{nm}$ using spectrophotometer in three replications. Standard curve of gallic acid solution $(0,10,25,50$ and $100 \mathrm{ppm})$ was prepared using the similar procedure. The results were expressed as $\mathrm{mg}$ GAE/g FW.

\subsection{Determination of Phenolic Compounds using HPLC}

Methanol $(\mathrm{MeOH})$ and chemical standards of scopoletin, rutin hydrate and quercetin were obtained from Sigma-Aldrich (St. Louis, MO, USA). The standards were accurately weighed and then dissolved in appropriate volume of $\mathrm{MeOH} /$ deionized water to produce corresponding stock standard solutions. Working standard solutions for calibration curves were prepared by diluting stock solutions with $\mathrm{MeOH}$ at different concentrations. All stock and working solutions were maintained at $0^{\circ} \mathrm{C}$. Deionized water was used throughout. Samples were kept at $20^{\circ} \mathrm{C}$ before analysis and filtered through a $0.22 \mu \mathrm{m}$ membrane filter (Iwaki Glass) and injected directly into the HPLC.

The HPLC analysis on phenolic compounds were performed according to the modified method of Analytical HPLC Application 031481, Merck, USA (2008). The system consisted of chromatographic separation performed on a Shimadzu Chromatography 20A with photodiode array detector (PDA), and equipped with Chromolith Performance RP-18 endcapped, Merck, UK (Cat. No. 1.02129). The pump was connected to a mobile phase system composed of two solvents: $A$; Methanol/ deionized water (2.5: 97.5, v/v) and B; Methanol/ deionized water $(50: 50, v / v)$. The mobile phase was programmed consecutively in linear gradient as follows: 0-10 min, 100\% A, 0\% B; 10-15 min, $65 \% \mathrm{~A}, 35 \% \mathrm{~B} ; 15-20 \mathrm{~min}, 0 \% \mathrm{~A}, 100 \% \mathrm{~B} ; 20-22 \mathrm{~min}$, $100 \% \mathrm{~A}, 0 \% \mathrm{~B}$; and $22-25 \mathrm{~min}, 100 \% \mathrm{~A}, 0 \% \mathrm{~B}$. The elution was ran at a flow rate of $2.1 \mathrm{~mL} / \mathrm{min}$ at 25 min. The gradient was selected as it afforded a good separation and symmetrical peak shape of target analytes in the HPLC chromatograms. The UV spectra was monitored in the range of 210 to $450 \mathrm{~nm}$ for the quantitative analysis. Sample peaks in the chromatograms derived from the photodiode array were integrated at $365 \mathrm{~nm}$. The injection volume was $20 \mu \mathrm{L}$ for each of the sample and standard solutions. The column temperature was maintained at $30^{\circ} \mathrm{C}$. Quantification was based on the peak area measurement. Characterization of the three phenolic compounds were achieved by comparing the HPLC retention time and absorption of target peaks in the samples with those of the standards. Data collection and integration were performed using Shimadzu Lab Solution software.

\subsection{Statistical Analysis}

Three replications were used for all parameters measured. Analysis of the data was analyzed using Excel (Microsoft Inc.) and SAS version 6.12. Statistical tests used were ANOVA and Duncan's Multiple Range test. Data obtained were reported as mean + standard deviation.

\subsection{RESULTS AND DISCUSSION}

\subsection{Effect of pH on Adsorption Capacity}

In this study, the influence of $\mathrm{pH}$ on adsorption of hexanoic acid is shown in Figure 2. Control sample A (hexanoic acid solution without resin and agitation) and $B$ (hexanoic acid solution without resin with agitation) gave significantly ( $p<0.05$ ) lowest adsorption capacity among all treatments, but both are not significantly different to hexanoic acid solution at $\mathrm{pH} 2$ and 3 . As $\mathrm{pH}$ increased, the adsorption capacity of hexanoic solution increased. Thereafter, the adsorption capacity remained high up to $\mathrm{pH} 11$. The highest $(\mathrm{p}<0.05)$ adsorption capacity of hexanoic solution was found at $\mathrm{pH} 10$ and 11 .

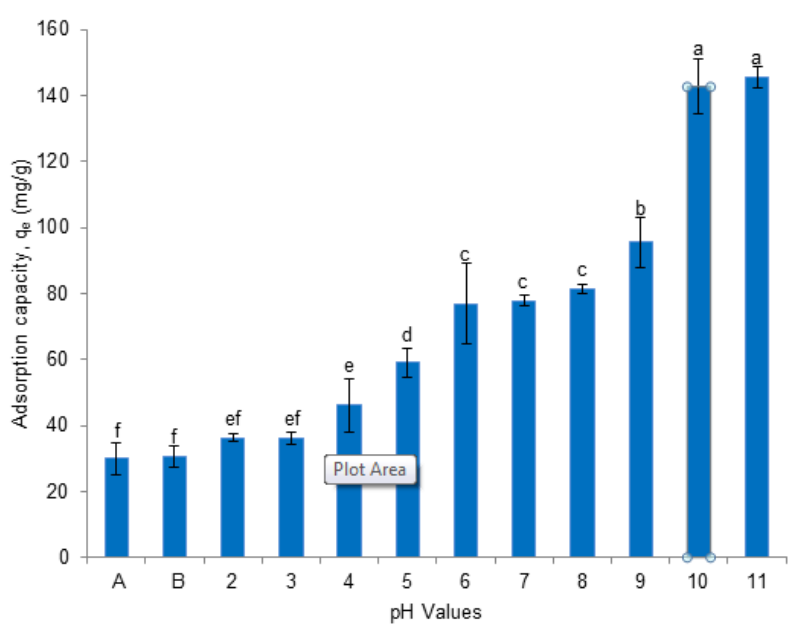

Figure 2 Effect of $\mathrm{pH}$ of hexanoic acid on the adsorption by weakly base ion exchange resin Amberlite IRA 67 (Volume: $20 \mathrm{ml}$; resin mass: $100 \mathrm{mg}$; temperature: $303 \mathrm{~K}$; agitation speed: $120 \mathrm{rpm})$. A: Hexanoic acid solution without resin and agitation, B: Hexanoic acid solution without resin with agitation

Figure 3 shows the effect of octanoic acid solution at different $\mathrm{pH}$ on the adsorption of Amberlite IRA 67. As obtained for hexanoic acid solution, there is no significant difference between control samples A and B. However, both control samples gave significantly $(p<0.05)$ higher adsorption capacity in octanoic acid solution compared to treated samples with $\mathrm{pH}$ modification $(\mathrm{pH} 2$ to 11). The trend for treated octanoic acid solution was similar as in hexanoic acid where there 
was an increase of adsorption capacity as the $\mathrm{pH}$ values increased. In the octanoic acid solution, it was found that no significant difference between samples of $\mathrm{pH} 8$ to 11 . Octanoic acid solution showed significantly $(\mathrm{p}<0.05)$ the highest adsorption capacity at these $\mathrm{pH}$ values compared to other $\mathrm{pH}$ studied.

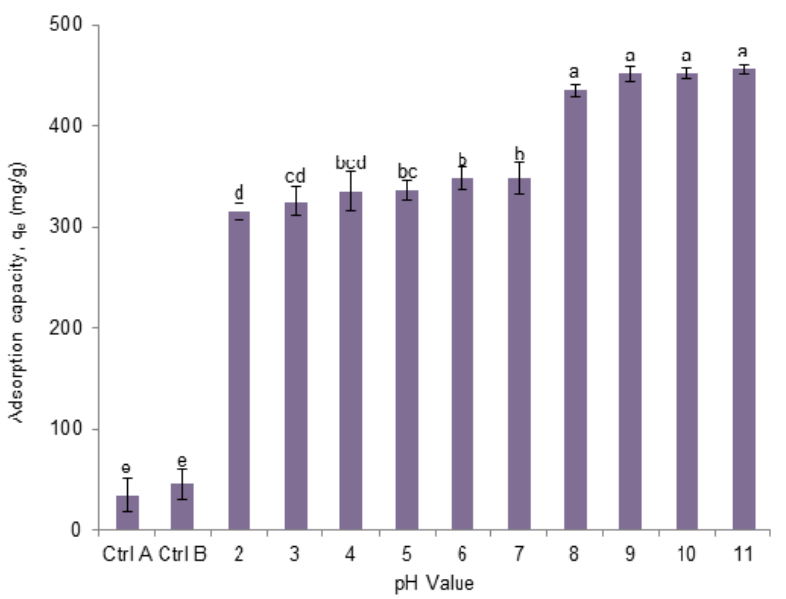

Figure 3 Effect of $\mathrm{pH}$ of octanoic acid on the adsorption by weakly base ion exchange resin Amberlite IRA 67 (Volume: $20 \mathrm{ml}$; resin mass: $100 \mathrm{mg}$; temperature: $303 \mathrm{~K}$; agitation speed: $120 \mathrm{rpm})$. A: Octanoic acid solution without resin and agitation, B: Octanoic acid solution without resin with agitation

The trend of adsorption capacity of these organic acid solutions in single compound were quite similar. Adsorption of organic acids (hexanoic and octanoic acid) on the resin surface can be affected by $\mathrm{pH}$ of solution, due to the rate of protonation of the compounds in aqueous solution. The adsorption capacity increases with increasing $\mathrm{pH}$ values. It can be explained by the reduction of the positive repulsive interactions between functional groups at high $\mathrm{pH}$. Therefore, the adsorption of low acidic solution is more favoured. A similar phenomenon was reported in the study done by [26] during the adsorption of polyethyleneimine using anion exchange resin.

The effect of $\mathrm{pH}$ in the solution on the adsorption capacity, qe (mg/g) of rutin on Amberlite IRA 67 was studied at a pH range of 2-11 as shown in Figure 4. The experiment was performed with an initial rutin concentration of $25 \mathrm{mg} / \mathrm{L}$, at $303 \mathrm{~K}$ with a contact time of 327 min. Control samples A and B gave significantly $(p<0.05)$ lowest adsorption capacity among all the treatments, but both are not significantly different.

Agitation rate and time did not affect the concentration of rutin. Rutin solutions were adsorbed by the Amberlite IRA 67 at all $\mathrm{pH}$ ranges. This could explain that $\mathrm{pH}$ of the solution gives significant effect on biosorption process as mentioned by [27]. At $\mathrm{pH} 2$, adsorption capacity is significantly $(p<0.05)$ the lowest compared to other $\mathrm{pH}$ studied. It gradually increased with increasing
$\mathrm{pH}$ values up to $\mathrm{pH}$ 11. Rutin solution showed significantly $(p<0.05)$ the highest adsorption capacity at $\mathrm{pH} 11$.

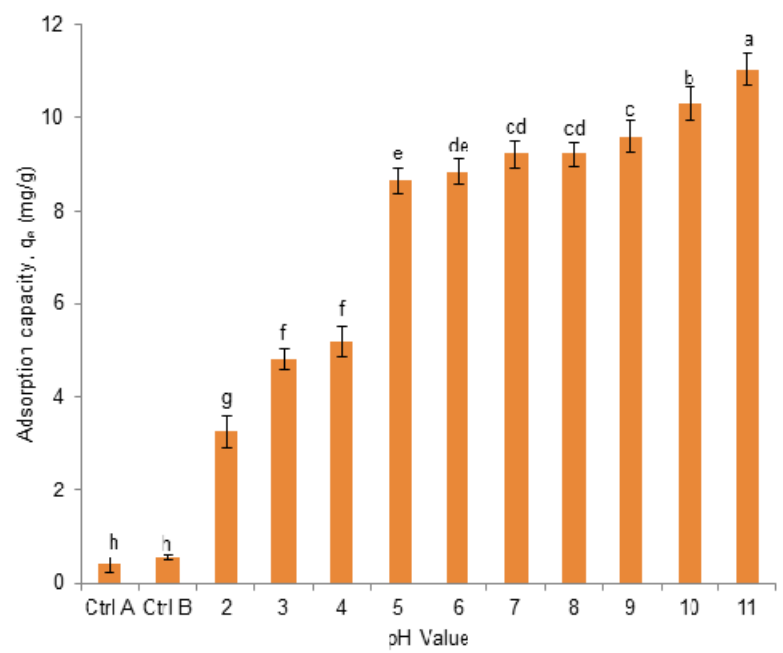

Figure 4 Effect of $\mathrm{pH}$ of rutin on the adsorption by weakly base ion exchange resin Amberlite IRA 67 (Volume: $20 \mathrm{ml}$; resin mass: $100 \mathrm{mg}$; temperature: $303 \mathrm{~K}$; agitation speed: $120 \mathrm{rpm})$. A: Rutin solution without resin and agitation, B: Rutin solution without resin with agitation

Figure 5 shows the effect of $\mathrm{pH}$ in the solution on the adsorption capacity, $q_{e}(\mathrm{mg} / \mathrm{g})$ of scopoletin on Amberlite IRA 67 in different $\mathrm{pH}$ ranges. Similar to rutin solution, no significant difference between control sample A and B of scopoletin solution but gave significantly $(p<0.05)$ the lowest adsorption capacity among all the $\mathrm{pH}$ studied. There were no significant difference of scopoletin solution at $\mathrm{pH} 2$ up to $\mathrm{pH} 5$, then increased significantly $(\mathrm{p}<0.05)$ to $\mathrm{pH}$ 6. At $\mathrm{pH} 7$ and 8, also no significant difference observed until it reached $\mathrm{pH} 9$ to 11 which showed significantly $(p<0.05)$ the highest adsorption capacity.



Figure 5 Effect of $\mathrm{pH}$ of scopoletin on the adsorption by weakly base ion exchange resin Amberlite IRA 67 (Volume: $20 \mathrm{ml}$; resin mass: $100 \mathrm{mg}$; temperature: $303 \mathrm{~K}$; agitation speed: $120 \mathrm{rpm})$. A: Scopoletin solution without resin and agitation, B: Scopoletin solution without resin with agitation 
Figure 6 displays the effect of $\mathrm{pH}$ in the solution on the adsorption capacity, qe $(\mathrm{mg} / \mathrm{g})$ of quercetin on Amberlite IRA 67 in different $\mathrm{pH}$. As can be seen in the figure, no significant difference was observed between control sample $A$ and B. Similar to rutin and scopoletin solution, agitation rate and time did not affect to the adsorption capacity of quercetin solution. However, a significant $(p<0.05)$ increase in adsorption capacity of quercetin solution was observed as $\mathrm{pH}$ values increase from $\mathrm{pH} 2$ to 4 , and from $\mathrm{pH} 4$ to 5 , and again started increasing significantly $(\mathrm{p}<0.05)$ at $\mathrm{pH} 8$. Adsorption capacity of quercetin solution reached the highest adsorption capacity at $\mathrm{pH} 11$.

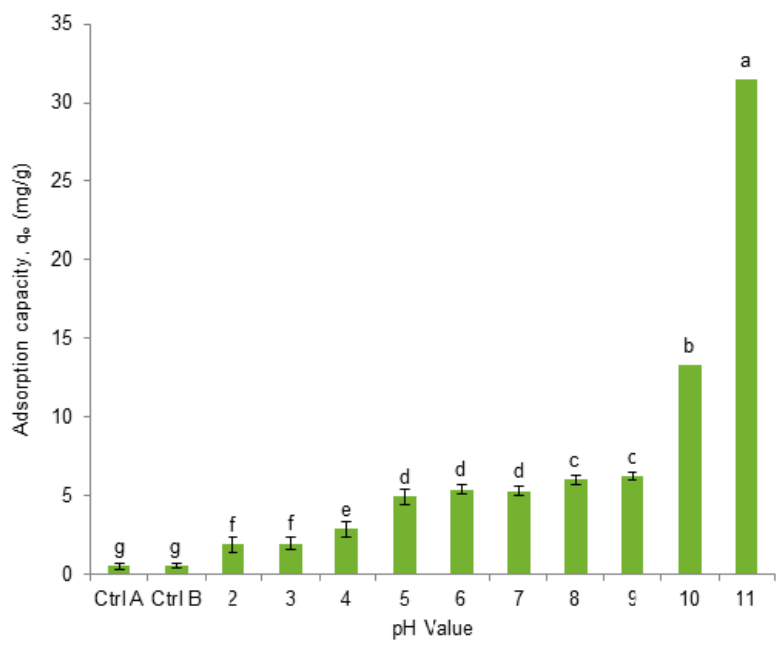

Figure 6 Effect of $\mathrm{pH}$ of quercetin on the adsorption by weakly base ion exchange resin Amberlite IRA 67 (Volume: $20 \mathrm{ml}$; resin mass: $100 \mathrm{mg}$; temperature: $303 \mathrm{~K}$; agitation speed: $120 \mathrm{rpm})$. A: Quercetin solution without resin and agitation, B: Quercetin solution without resin with agitation

The trend of these three phenolic compounds on adsorption capacity were quite similar. The adsorption capacity was low at highly acidic medium and gradually increased with increasing $\mathrm{pH}$ values up to $\mathrm{pH} 11$. This might be due to the decrease in competition between the charged ions for the same functional group of the resin used. According to [28], a change of the $\mathrm{H}_{3} \mathrm{O}^{+}$ concentration in the solution resulted changes in the ratio of protonated/ unprotonated polyphenolic compounds. Protonation of these polyphenolic compounds significantly changes their charges as well the affinity to negatively charged adsorption resin Amberlite IRA 67. However, the results might be different from other phenolic compounds as phenolic profile vary in their molecular sizes and form which influences their solubility and adsorption [29].

\subsection{Effect of Single Compound on Antioxidant Activity and Total Phenolic Compounds}

Figure 7 indicates total phenolic content of the rutin solution at different $\mathrm{pH}$ ranges during adsorption process using Amberlite IRA 67. Sample control A and $B$ did not give significant effect on agitation rate and time as discussed earlier. Sample controls of rutin solution significantly $(p<0.05)$ showed the highest phenolic content compared to all rutin solution with $\mathrm{pH}$ modification. However, no significant different observed for rutin solution at $\mathrm{pH} 5$ to other $\mathrm{pH}$ values except for $\mathrm{pH} 11$. Rutin solution at $\mathrm{pH} 5$ was only significantly different $(\mathrm{p}<0.05)$ to $\mathrm{pH}$ of 11 . Overall, the trend shows $\mathrm{pH}$ did not give a significant effect on rutin solution in single compounds studied except at $\mathrm{pH} 11$.

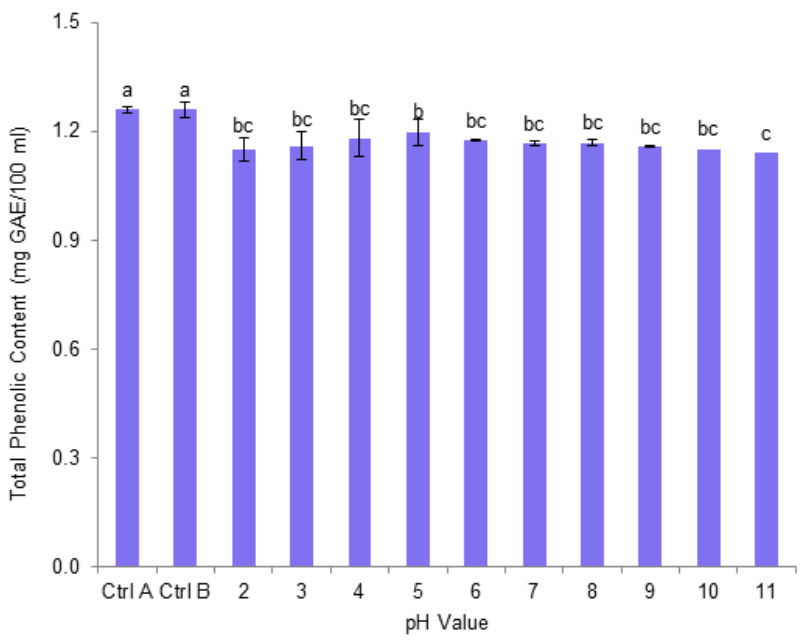

Figure 7 The effect of TPC of single compound (rutin $=25$ ppm) using Amberlite IRA 67 resin at different $\mathrm{pH}$ (Resin amount $100 \mathrm{mg}$; agitation rate: $120 \mathrm{rpm})$. A: Rutin solution without resin and agitation, B: Rutin solution without resin with agitation

The effect of ferric reducing activity ( $\mu \mathrm{mol} / \mathrm{g}$ ) of rutin solution on Amberlite IRA 67 were shown in Figure 8. From the figure, all rutin solution treated with the resin were significantly $(p<0.05)$ lower compared to both control samples ( $A$ and $B$ ) for FRAP. There was no significant difference for FRAP between sample control A and B. Similar to adsorption capacity, agitation rate and time did give much effect on antioxidant losses. As can be seen in Figure 8, rutin solution at $\mathrm{pH} 5$ shows the best ferric reducing activity with significantly $(\mathrm{p}<0.05)$ different to the rutin solution at $\mathrm{pH} 2,3,9,10$ and 11 . The trend of ferric reducing activity of rutin solution might be due to the degradation rate constant with $\mathrm{pH}$ indicated that rutin solution was stable at lower acidic condition and lower alkaline condition [30]. 


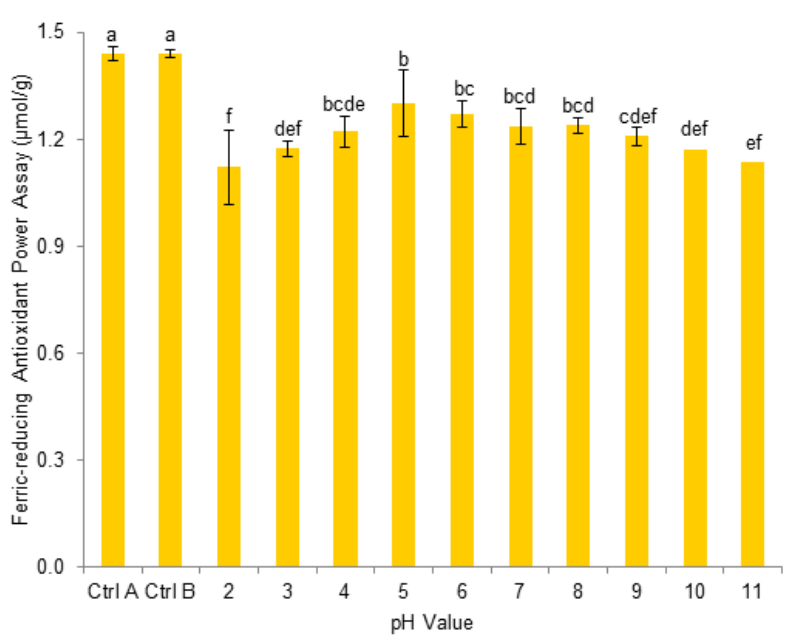

Figure 8 The effect of antioxidant activity (FRAP) of single compound (rutin $=25 \mathrm{ppm}$ ) using Amberlite IRA 67 resin at different $\mathrm{pH}$ (Resin amount $100 \mathrm{mg}$; agitation rate: $120 \mathrm{rpm}$ ). A: Rutin solution without resin and agitation, B: Rutin solution without resin with agitation

Results of the free radical scavenging activity for rutin solution are presented in Figure 9. As expected, both control samples (A and B) are not significantly different but significantly $(\mathrm{p}<0.05)$ showed the highest among all rutin solution with $\mathrm{pH}$ adjustment. DPPH radical scavenging activity of rutin solution at $\mathrm{pH}$ of 2 , $8,9,10$ and 11 are considered significantly $(p<0.05)$ lower as compared to the $\mathrm{pH} 3$ to 7 . There was no significant different at this $\mathrm{pH}$ range. As reported by [31], most phenolic compounds in plants show maximum polyphenoloxidase (PPO) activity at or near neutral $\mathrm{pH}$ values. The trend is similar with ferric reducing power of rutin where it shown the stability of the compound closer to the neutral $\mathrm{pH}$ regime. However, as the $\mathrm{pH}$ value increase, percentage of free radical scavenging activity gradually decreased. The lowest $(p<0.05)$ scavenging activity of rutin solution was found at $\mathrm{pH} 11$. Phenolic compounds are known as powerful chain breaking antioxidants [32]. Phenolic compounds including rutin are very important constituents of plants and their radical scavenging ability is due to their hydroxyl groups [30]. The phenolic compounds may contribute directly to antioxidative action [33].

Effect of pH during adsorption process of phenolic compounds has been investigated previously by many researchers. Most of them relate it to the degree of ionization of the phenolic sorbate. At pH > pKa the compounds are mainly in the form of negatively charged phenoxy ions, while the functional groups of the carbon surface are deprotonated and negatively charged. In addition to that, the electrostatic repulsion leads to a decrease of the adsorption capacity. On the contrary, when $\mathrm{pH}<\mathrm{pKa}$ the phenolic compounds are predominantly in the neutral molecular form, while the surface acidity increases favoring the donor-acceptor interaction between the electrons of the aromatic ring and the surface. It leads to an increase of the adsorption capacity. Conversely, at low $\mathrm{pH}$, the phenolic acids are hardly soluble in water. It means that for purification purpose only a narrow range of $\mathrm{pH}$ is possible: within this range the phenolic species must be water-soluble, i.e., slightly ionized, but not too much to be adsorbable onto the solid [34].

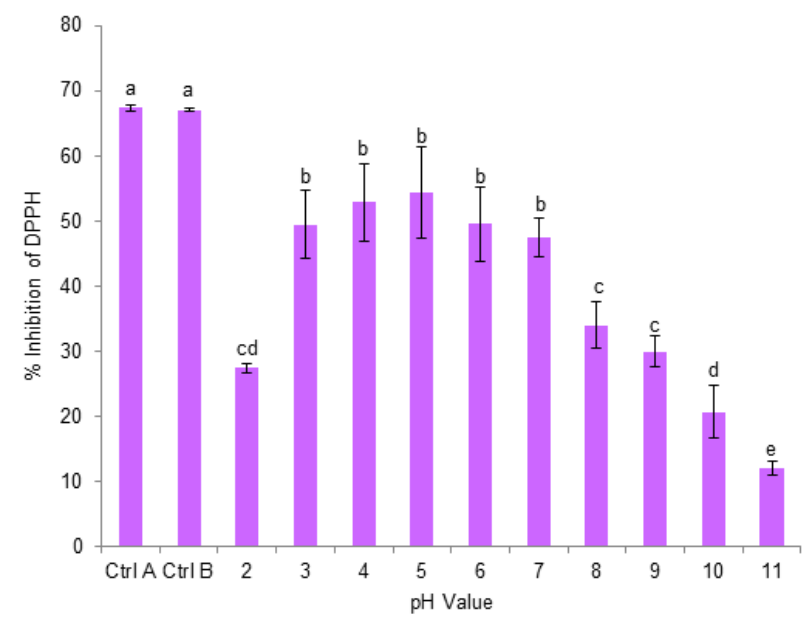

Figure 9 The effect of antioxidant activity (DPPH) of single compound (rutin $=25 \mathrm{ppm}$ ) using Amberlite IRA 67 resin at different $\mathrm{pH}$ (Resin amount $100 \mathrm{mg}$; agitation rate: $120 \mathrm{rpm}$ ). A: Rutin solution without resin and agitation, B: Rutin solution without resin with agitation

Figure 10 shows total phenolic content of scopoletin solution at different $\mathrm{pH}$ range $(\mathrm{pH} 2$ 11). It was observed that no significant difference existed in both control samples (A and B) as observed in rutin solution. However, control samples significantly $(\mathrm{p}<$ 0.05) affected other scopoletin solution which undergo $\mathrm{pH}$ modification. Scopoletin solution at $\mathrm{pH}$ of 3 to 5 were not significantly different with the solution at $\mathrm{pH} 2,6,7$ and 8 but decreased significantly $(\mathrm{p}<0.05)$ when it reached $\mathrm{pH} 9$ and subsequently $\mathrm{pH} 10$. Results showed significantly $(\mathrm{p}<$ 0.05) the lowest phenolic content of scopoletin solution at $\mathrm{pH} 11$. 


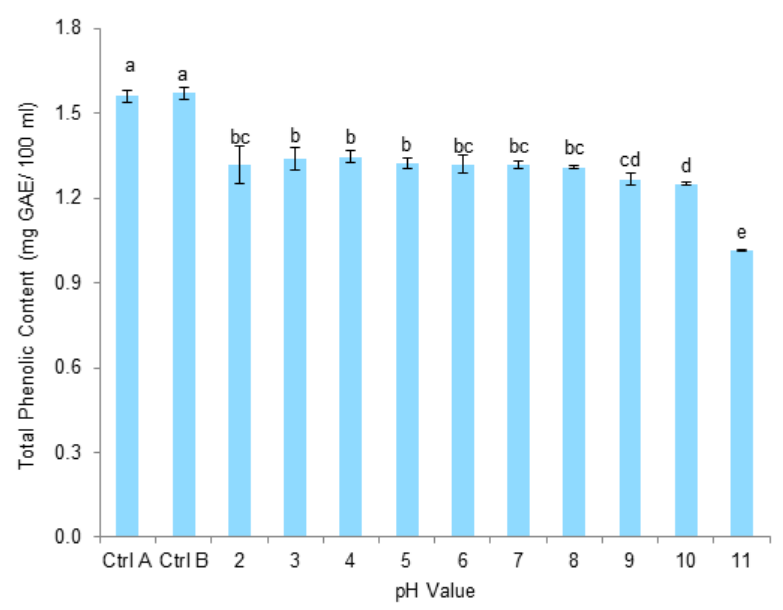

Figure 10 The effect of TPC of single compound (scopoletin $=25 \mathrm{ppm}$ ) using Amberlite IRA 67 resin at different pH (Resin amount $100 \mathrm{mg}$; agitation rate: $120 \mathrm{rpm})$. A: Scopoletin solution without resin and agitation, B:Scopoletin solution without resin with agitation

According to Figure 11, the trend of ferric reducing power looks similar to total phenolic content of scopoletin solution. As expected, no significant difference was found between control samples (A and $B$ ) but the control samples showed the highest ferric reducing power. As for treated scopoletin solution, the solution adjusted at $\mathrm{pH} 4$ significantly $(p<0.05)$ showed the highest ferric reducing power as compared to other $\mathrm{pH}$ studied except for $\mathrm{pH} 3$ and 5. The same phenomenon happened in rutin solution where the highest ferric reducing power or $\mathrm{pH}$ stability of the scopoletin was found at lower acidic condition.

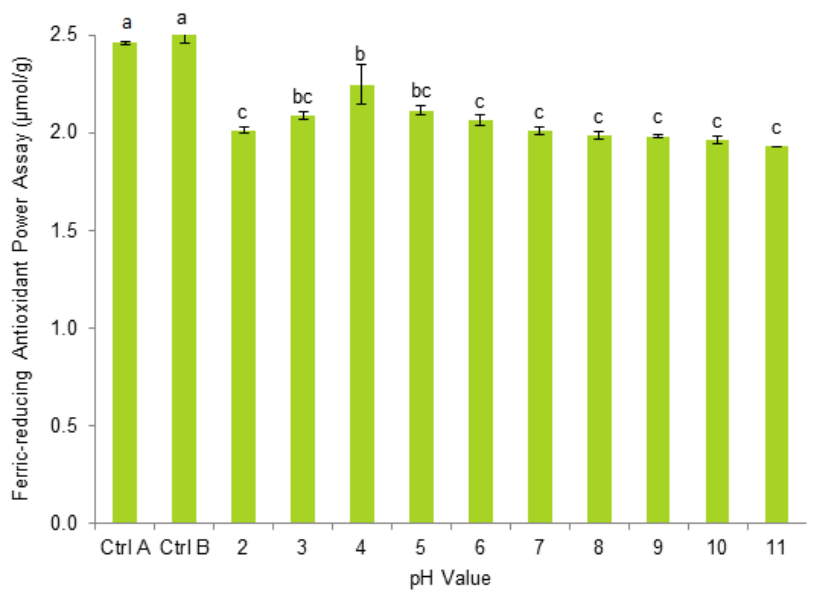

Figure 11 The effect of antioxidant activity (FRAP) of single compound (scopoletin $=25 \mathrm{ppm}$ ) using Amberlite IRA 67 resin at different $\mathrm{pH}$ (Resin amount $100 \mathrm{mg}$; agitation rate: $120 \mathrm{rpm})$. A: Scopoletin solution without resin and agitation, $B: S c o p o l e t i n$ solution without resin with agitation

The DPPH free radical scavenging activity of scopoletin solution at different $\mathrm{pH}$ ranges is shown in
Figure 12. All treated samples of scopoletin solution using Amberlite IRA 67 resulted in significantly lower $(p<0.05)$ free radical scavenging activity when compared to the control (A and B). At higher acidity $(\mathrm{pH} 2)$ of the solution, the scavenging activity seems slower and started to increase with increasing $\mathrm{pH}$ values up to $\mathrm{pH}$ 6. Scopoletin solution at $\mathrm{pH} 6$ showed significantly $(p<0.05)$ the highest free radical scavenging activity of the solution compared to the other treated solution. It shows DPPH free radical scavenging activity of scopoletin solution also was stability at lower acidic condition. Subsequently, scopoletin solution started to decrease gradually until it reached $\mathrm{pH} 11$.

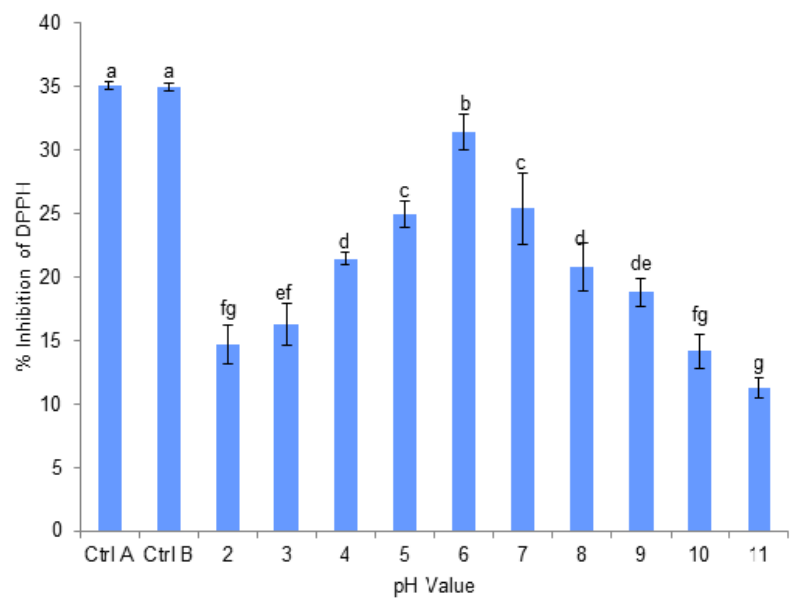

Figure 12 The effect of antioxidant activity (DPPH) of single compound (scopoletin $=25 \mathrm{ppm}$ ) using Amberlite IRA 67 resin at different $\mathrm{pH}$ (Resin amount $100 \mathrm{mg}$; agitation rate: $120 \mathrm{rpm})$. A: Scopoletin solution without resin and agitation, B:Scopoletin solution without resin with agitation

Figure 13 shows total phenolic content of quercetin solution at different $\mathrm{pH}$ range $(\mathrm{pH} 2$ to 11) during adsorption process of Amberlite IRA 67. As displayed, it was found that no significant difference existed between control samples $A$ and $B$, whereas both samples have significantly $(p<0.05)$ higher phenolic content compared to other treated samples with $\mathrm{pH}$ modification. However, for treated quercetin solution, the solution adjusted at $\mathrm{pH} 3$ and 4 showed significantly $(p<0.05)$ higher phenolic content compared to other samples except for $\mathrm{pH} 2,5$ and 6 .

Figure 14 shows the effect of ferric reducing power for quercetin solution after treatment with Amberlite IRA 67 at different $\mathrm{pH}$. No significant difference were found in control samples $A$ and $B$ but both samples were significantly $(p<0.05)$ different compared to other treated quercetin solution. At $\mathrm{pH} 3$ and 4 , it showed the highest $(p<0.05)$ ferric reducing power of treated quercetin solution except for $\mathrm{pH} 5$. As the value of $\mathrm{pH}$ increase, the ferric reducing abilities of quercetin solution started to decrease. The $\mathrm{pH}$ value of the solution remains the same at $\mathrm{pH} 9$ to 11 with the lowest $(p<0.05)$ ferric reducing power. 


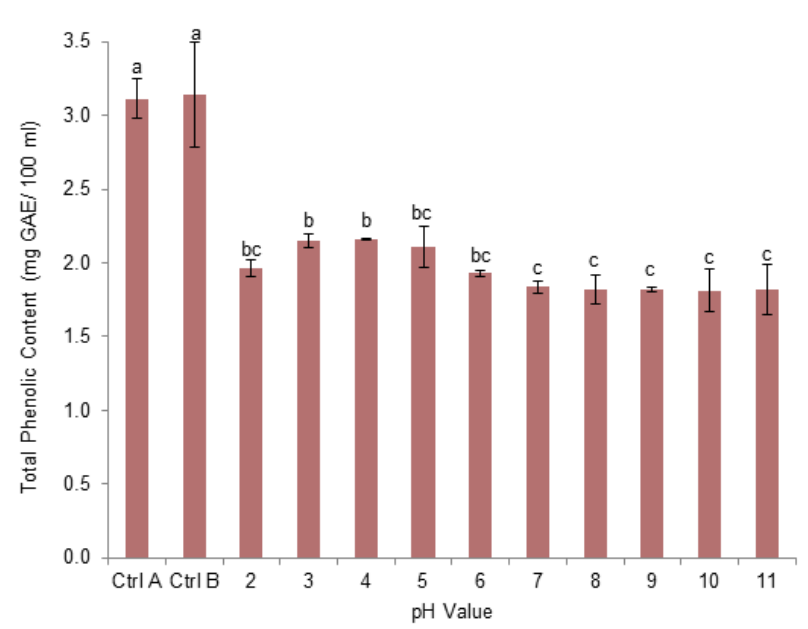

Figure 13 The effect of TPC of single compound (quercetin = 25 ppm) using Amberlite IRA 67 resin at different pH (Resin amount $100 \mathrm{mg}$; agitation rate: $120 \mathrm{rpm})$. A: Quercetin solution without resin and agitation, B:Quercetin solution without resin with agitation

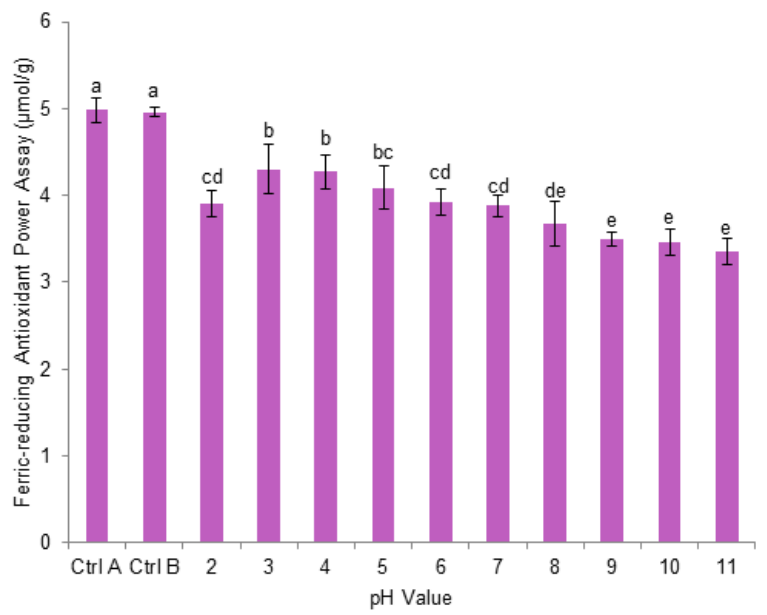

Figure 14 The effect of antioxidant activity (FRAP) of single compound (quercetin $=25 \mathrm{ppm}$ ) using Amberlite IRA 67 resin at different $\mathrm{pH}$ (Resin amount $100 \mathrm{mg}$; agitation rate: $120 \mathrm{rpm})$. A: Quercetin solution without resin and agitation, $B: Q u e r c e t i n$ solution without resin with agitation

As can be seen in Figure 15, DPPH free radical scavenging activity of quercetin solution showed the highest percentage in control samples A and B. At high acidity $(\mathrm{pH} 2)$, the percentage of scavenging activity of treated quercetin solution was low. It started to increase significantly $(\mathrm{p}<0.05)$ at $\mathrm{pH} 3$ and 4. When the $\mathrm{pH}$ was increased to $\mathrm{pH} 5$ quercetin solution significantly $(p<0.05)$ produced the highest scavenging activity compared to other treated quercetin solution. These results were similar to those obtained from the single compound of rutin and scopoletin solution where it shows the stability of the compound closer to the neutral pH regime. Beyond neutral $\mathrm{pH}$, scavenging activity of quercetin solution gradually decreased as it reaches stronger base.

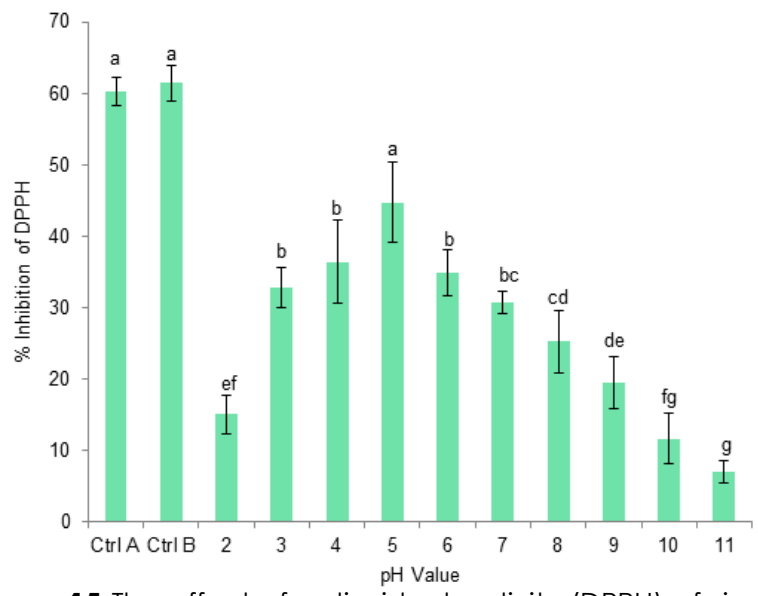

Figure 15 The effect of antioxidant activity (DPPH) of single compound (quercetin $=25 \mathrm{ppm}$ ) using Amberlite IRA 67 resin at different $\mathrm{pH}$ (Resin amount $100 \mathrm{mg}$; agitation rate: $120 \mathrm{rpm})$. A: Quercetin solution without resin and agitation, B:Quercetin solution without resin with agitation

\subsection{Effect of Multicompound on Adsorption of Organic Acids}

In this model system studied, multicompound solution were used to stimulate actual noni juice using identical values of $\mathrm{pH}$. As can be seen in Figure 16, there was no significant difference detected in both control samples A and B for hexanoic and octanoic acid. If compared to the adsorption capacity obtained in single solution, the trend observed for both compounds were similar. It shows an increase in adsorption capacity as the $\mathrm{pH}$ values increased. The highest adsorption capacity for hexanoic and octanoic acid were significantly $(p<0.05)$ obtained at $\mathrm{pH} 10$ to 11 and $\mathrm{pH} 9$ to 11 , respectively.

=Hexanoic acid $\quad$ Octanoic acid

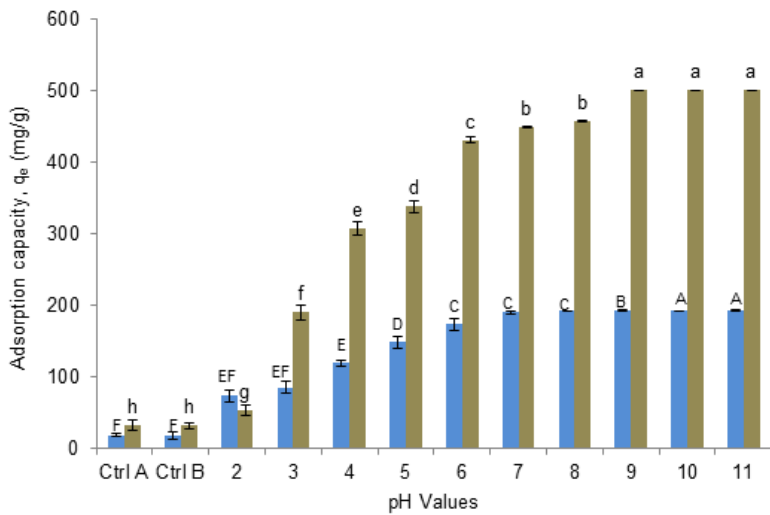

Figure 16 The effect of organic acids of multicompound (A0 $=25 \mathrm{ppm} ; \mathrm{OA}=250 \mathrm{ppm} ; \mathrm{HA}=100$ ppm) using Amberlite IRA 67 resin at different $\mathrm{pH}$ (Resin amount 100 mg; agitation rate: $120 \mathrm{rpm})$. A:Multicompound solution without resin and agitation, B:Multicompound solution without resin with agitation

*A-F Different capital letters in the same organic acid indicate significant difference $(p<0.05)$

*a-h Different letters in the same organic acid indicate significant difference $(p<0.05)$ 


\subsection{Effect of Multicompound on Antioxidant Activity and Total Phenolic Content}

The antioxidant activity and total phenolic content of multicompound in model system were also investigated at different $\mathrm{pH}$ values. Total phenolic content of multicompound solution during adsorption of Amberlite IRA 67 at different $\mathrm{pH}$ values is presented in Figure 17. The trend of the phenolic content was quite similar to those in single compound. As expected, no significant difference was found in control samples $A$ and $B$. It means that agitation time and rate also did not affect both control samples (A, without resin and agitation and $B$, without resin). Changes in various $\mathrm{pH}$ values influenced the phenolic content in treated samples. A significant $(p<0.05)$ reduction of phenolic content was observed for all samples treated with Amberlite IRA 67. No significant difference in multicompound solution between $\mathrm{pH}$ range 2 to 5 was observed. However, a decrease of phenolic content was found at higher $\mathrm{pH}$ values. The lowest phenolic content of multicompounds solution was obtained at $\mathrm{pH}$ of 11 .

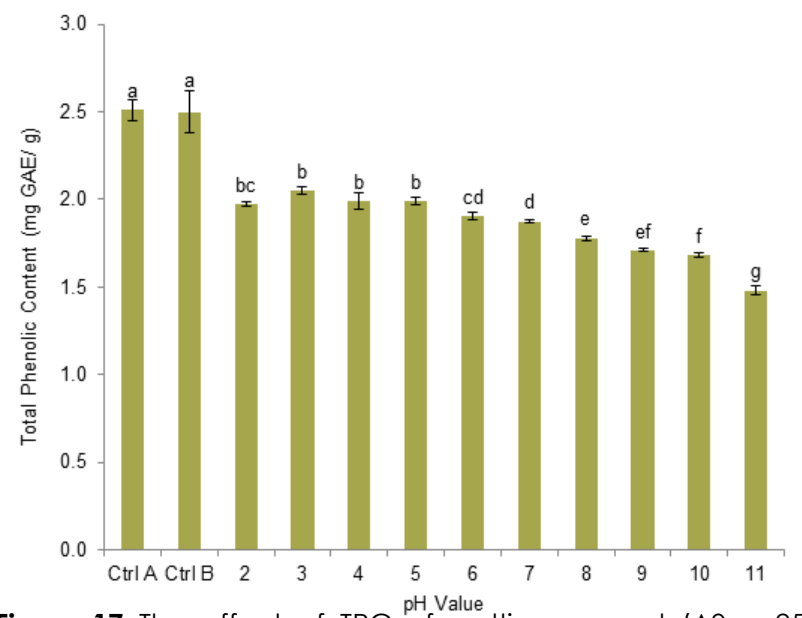

Figure 17 The effect of TPC of multicompound $(\mathrm{AO}=25$ ppm; OA = 250 ppm; $\mathrm{HA}=100$ ppm) using Amberlite IRA 67 resin at different $\mathrm{pH}$ (Resin amount $100 \mathrm{mg}$; agitation rate: $120 \mathrm{rpm})$. A:Multicompound solution without resin and agitation, B:Multicompound solution without resin with agitation

From Figure 18, it shows ferric reducing power of multicompounds solution during adsorption process using Amberlite IRA 67 at different $\mathrm{pH}$. Similar to the trend in total phenolic content of multicompounds solution, no significant difference was observed between both control samples A and B. However, the ferric reducing power of multicompounds solution decreased significantly $(p<0.05)$ in all multicompound solution treated samples with $\mathrm{pH}$ modification. At higher acidity ( $\mathrm{pH} 2)$, the ferric reducing power was significantly $(p<0.05)$ lower as compared to the multicompound solution at lower acidity ( $\mathrm{pH} 3$ to 6). The multicompound solution at $\mathrm{pH} 6$ shows the highest ferric reducing power indicating the strongest ability to reduce $\mathrm{Fe}$ (III) to $\mathrm{Fe}$ (II). Furthermore, an increase in $\mathrm{pH}$ values decreased the ferric reducing power. The lowest ferric reducing power of multicompound solution was found at $\mathrm{pH} 10$ and 11 .

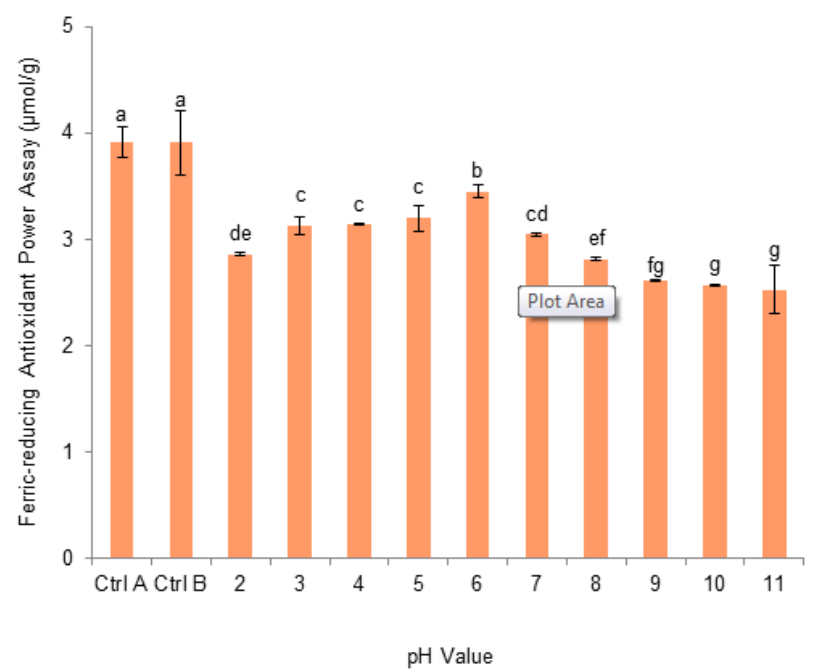

Figure 18 The effect of antioxidant activity (FRAP) of multicompound $(\mathrm{AO}=25 \mathrm{ppm} ; \mathrm{OA}=250 \mathrm{ppm} ; \mathrm{HA}=100$ ppm) using Amberlite IRA 67 resin at different pH (Resin amount $100 \mathrm{mg}$; agitation rate: $120 \mathrm{rpm}$ ). A:Multicompound solution without resin and agitation, B:Multicompound solution without resin with agitation

Figure 19 shows DPPH free radical scavenging activity of multicompound solution during adsorption process of Amberlite IRA 67 at different $\mathrm{pH}$ range. No significant difference was observed in control samples A and B. The DPPH free radical scavenging activity This observation was also not significant for multicompound solutions that were adjusted to $\mathrm{pH} 4$ and 5. At higher acidity $(\mathrm{pH} 2)$, the scavenging activity of the solution seemed significantly $(p<0.05)$ lower compared to lower acidity (pH 4 and 5) except for $\mathrm{pH}$ 6. The scavenging activity of the multicompound solution tremendously decreased as the $\mathrm{pH}$ increased. The lowest $\mathrm{pH}$ value of multicompounds solution obtained at $\mathrm{pH} 10$ and 11 .

There was a similar trend observed in antioxidant activity (FRAP and DPPH) of multicompound solution compared to those obtained in single solution. As mentioned by previous researchers [35], $\mathrm{pH}$ of the surrounding medium influenced the radical scavenging capacity of phenolic compounds. $\mathrm{pH}$ dependence for antioxidation activity against lipid oxidation and stable radicals can, at least in part, be related to the deprotonation of an $\mathrm{OH}$ moiety. The actual mechanism of antioxidant action of the deprotonated forms can be either hydrogen atom or electron donation or both [36]. 


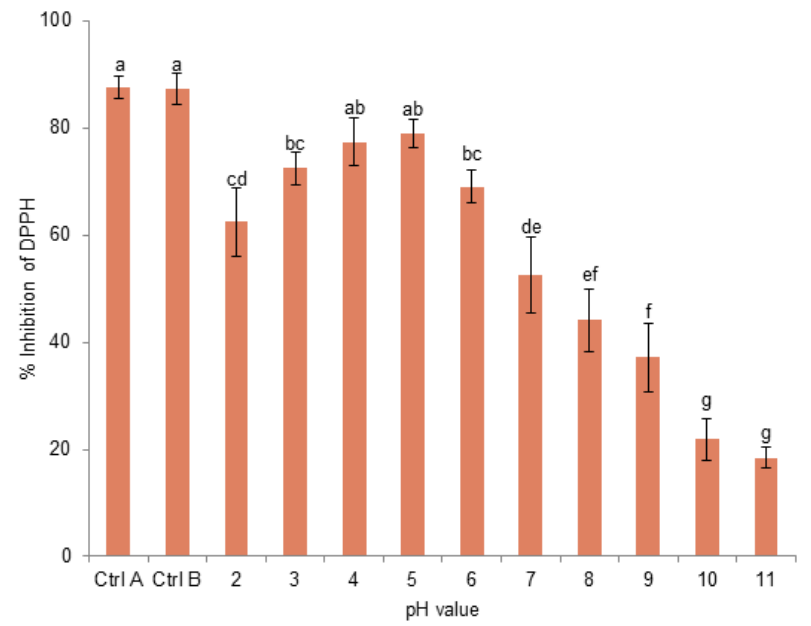

Figure 19 The effect of antioxidant activity (DPPH) of multicompound $(\mathrm{AO}=25 \mathrm{ppm} ; \mathrm{OA}=250 \mathrm{ppm} ; \mathrm{HA}=100$ ppm) using Amberlite IRA 67 resin at different $\mathrm{pH}$ (Resin amount $100 \mathrm{mg}$; agitation rate: $120 \mathrm{rpm}$ ). A:Multicompound solution without resin and agitation, B:Multicompound solution without resin with agitation

Figure 20 presents selected phenolic compounds (scopoletin, rutin and quercetin) in multicompound system at different $\mathrm{pH}$ range (2 to 11) including control samples. From the observation, there was no siginificant difference between both control samples (A and B) for scopoletin and quercetin but significantly $(p<0.05)$ lower in treated samples with $\mathrm{pH}$ modification. There was no significant difference found in rutin control samples ( $\mathrm{A}$ and $\mathrm{B}$ ) and also rutin solution at $\mathrm{pH} 2$ - 4. As the $\mathrm{pH}$ increased, each phenolic compound seemed to decrease until $\mathrm{pH}$ 11. The lowest concentration of each phenolic compound was determined at $\mathrm{pH} 11$ which were significantly different $(p<0.05)$ among other treated samples.

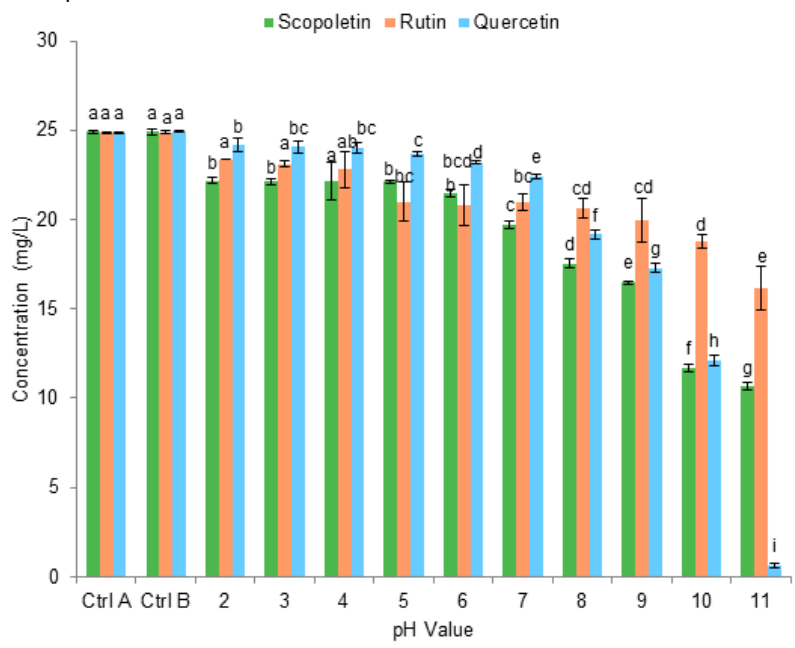

Figure $20 \mathrm{HPLC}$ determination of multicompound $(\mathrm{A} 0=25$ ppm; OA = 250 ppm; $\mathrm{HA}=100$ ppm) using Amberlite IRA 67 resin at different $\mathrm{pH}$ (Resin amount $100 \mathrm{mg}$; agitation rate: $120 \mathrm{rpm})$. A:Multicompound solution without resin and agitation, B:Multicompound solution without resin with agitation

*Different letters in the same phenolic compounds indicate significant difference $(p<0.05)$
The relationship between antioxidant compounds and antioxidant activities are complicated [37]. As mentioned by [38], antioxidant activity depends on the amount of antioxidants, structure and interactions among each other. The structure of phenolic compounds are an important determinant of the radical scavenging activity. According to [39], antioxidant activity rely on the number and position of the hydroxyl group in relation to the carboxyl functional group. In this case, it is also related to ionization process that occurs during $\mathrm{pH}$ modification of the samples studied. Therefore, high phenolic or flavonoid contents do not necessarily exhibit high antioxidant capacity. These results agree with $[40,41]$ and [37] who reported that differences in antioxidant activities could be due to the different qualitative compositions of phenolic constituents.

\subsection{CONCLUSION}

It was shown that the $\mathrm{pH}$ dependence of adsorption capacity of weak base anion exchange Amberlite IRA 67 resin had similar increasing trend on organic acids (hexanoic and octanoic acid) and phenolic compounds (rutin, scopoletin and quercetin) studied as $\mathrm{pH}$ values increased. In single solution of each phenolic compound, it was observed that total phenolic content (TPC) and antioxidant activity (FRAP and DPPH) gave highest values closer to neutral $\mathrm{pH}$ regime. The $\mathrm{pH}$ dependence of adsorption capacity in multicompounds solution also showed similar trend for organic acid compounds. Similar trend was also found in multicompounds solution of phenolic compounds in total phenolic content (TPC) and antioxidant activity (FRAP and DPPH). The findings of the present study are important for further investigation to be applied in actual system.

\section{Acknowledgement}

The authors would like to thank The Ministry of Education (MOE) for the scholarship, The Ministry of Science, Technology and Innovation (MOSTI) for financing the project under the ERGS/1/2013/STWN03/UKM/02/1 grant and Universiti Kebangsaan Malaysia, Bangi, Selangor, Malaysia.

\section{References}

[1] Deng, S., West, B. J., Jensen, J., Basar, S., Westendorf, J. 2009. Development and Validation of an RP-HPLC Method for the Analysis of Anthraquinones in Noni Fruits and Leaves. Food Chemistry. 116(2): 505-508.

[2] Dixon, A. R., McMillen, H., Ełkin, N. L. 1999. Ferment this: The Transformation of Noni, A Traditional Polynesian Medicine (Morinda citrifolia, Rubiaceae). Economic Botany. 53: 51-68.

[3] Wang, M.Y., Su, C. 2001. Cancer Preventive Effect on Morinda citrifolia (Noni). Annals of the New York Academy of Sciences. 952: 161-168. 
[4] Norma, H., Normah, A., Ahmad, A. W., Rohani, M. Y. Muhammad Gawas, M., Sharizan, A. 2004. Reducing the Smelly Compounds (caproic, caprylic and capric acids) in Noni by Treating the Juice with Activated Charcoal Powder. Proceeding of the National Food Technology Seminar.

[5] Sharmella, U. H., Maskat, M. Y., Osman, H. 2005. Physicochemical Ropeprties of Deacidified Noni Extract using Calcium Carbonate. Proceeding of the 8th Applied Biology Symposium 2005 Kuala Lumpur. 22-23 Jun.

[6] Maskat, M. Y. 2006. Effect of Deacidification on the Physico-chemical and Sensory Properties of Noni Extract. Final Report of ST-024-2005.

[7] Nur Hafiza, Z., Maskat, M. Y., Liew, S. L., Mamot, S. 2013. Fermentation of Morinda citrifolia Extract by Saccharomyces cerevisiae as Affected by Substrate Concentration, Inoculum Size, Temperature and Fermentation Time. International Food Research Journal. 20(4): 1889-189.

[8] Haslaniza, H., Wan Yaacob, W. A., Osman, H., \& Maskat, M. Y. 2015. Interaction of Antioxidants and Organic Acid from Noni (Morinda citrifolia L.) Juice with Ion Exchange Resins during Deodorization via Deacidification. Der Pharma Chemica. 7(9): 9-21.

[9] Zin, Z. M., Hamid, A. A., Osman, A., Saari, N. 2006. Antioxidative Activities of Chromatographic Fractions Obtained from Root, Fruit and Leaf of Mengkudu (Morinda citrifolia L.). Food Chemistry. 94(2): 169-178.

[10] Deng, S., West, B. J., Jensen, C. J. 2010. A Quantitative Comparison of Phytochemical Components in Global Noni Fruits and Their Commercial Products. Food Chemistry. 122(1): 267-270.

[11] Wang, M. Y., Su, C. 2001. Cancer Preventive Effect on Morinda citrifolia (Noni). Annals of the New York Academy of Sciences. 952: 161-168.

[12] Pawlus, A. D., Kinghorn, D. A. 2007. Review of the Ethnobotany, Chemistry, Biological Activity and Safety of The Botanical Dietary Supplement Morinda citrifolia (noni). Journal of Pharmacy and Pharmacology. 59(12): 1587609.

[13] Potterat, O. 2007. Morinda citrifolia (noni) Fruit Phytochemistry, Pharmacology, Safety. Planta Medica. 73: 191-199.

[14] Wang, M. Y., West, B. J., Jensen, C. J., Nowicki, D., Su, C. Palu, A. K., Anderson, G. 2002. Morinda citrifolia (Noni): A Literature Review and Recent Advances in Noni Research. Acta pharmocologica Sinica. 23(12): 11271141

[15] Morton, J. 1992. The Ocean Going Noni, or Indian Mulberry (Morinda citrifolia, Rubiaceae) and some of Its "Colorful" Relatives. Economic Botany. 46: 241-256.

[16] Dittmar, A. 1993. Morinda citrifolia L: Use in Indigenous Samoan Medicine. Journal of Herbs and Medicinal Plants. $1(3)$.

[17] Hasnain Isa, M., Lee, S. L., Faridah, A. H. A., Hamidi, A. A., Azam, N. R., Jaya Paul, A.D. 2007. Low Cost Removal of Disperse Dyes from Aqueous Solution using Palm Ash. Dyes and Pigments. 74(2): 446-453.

[18] Datta, C., Dutta, A., Dutta, D., Chaudhuri, S. 2011. Adsorption of Polyphenols from Ginger Rhizomes on An Anion Exchange Resin Amberlite IR-400 - Study on Effect of $\mathrm{pH}$ and Temperature. Procedia Food Science. 1 (Icef 11): 893-899.

[19] Cretkovic, D., Markovic, D., Cvetkovic, D., Radovanovic, B. 2011. Effects of Continuous UV-Irradiation on The Antioxidant Activities of Quercetin and Rutin in Solution in The Presence of Lecithin as The Protective Target. Journal of the Serbian Chemical Society. 76(7): 973-985.

[20] Cheng, Z. 2012. Studies on The Interaction between Scopoletin and Two Serum Albumins by Spectroscopic Methods. Journal of Luminescence. 132(10): 2719-2729.

[21] Hafizah, Y. 2011. The effect of Deacidification on Noni (Morinda citrifolia L.) Extract Properties. Tesis Masters. Universiti Kebangsaan Malaysia, Malaysia.
[22] Zambonin, C. G., Quinto, M., De Vietro, N. \& Palmisano, F. 2004. Solid-phase Microextraction-Gas Chromatography Mass Spectrometry: A Fast And Simple Screening Method for The Assessment of Organophosphorus Pesticides Residues in Wine and Fruit Juices. Food Chemistry. 86: 269274.

[23] Benzie, I. F. F., Strain, J. J. 1996. Ferric Reducing Ability of Plasma (FRAP) as A Measure Of Antioxidant Power: The FRAP Assay. Analytical Biochemistry. 239: 70-76.

[24] Akowuah, G. A., Ismail, Z., Norhayati, I., Sadikun, A. 2005. The Effects of Different Extraction Solvents of Varying Polarities on Polyphenols of Orthosiphon Stamineus and Evaluation of The Free Radical-Scavenging Activity. Food Chemistry. 93(2): 311-317.

[25] Singleton, V. L., Rossi, J. A. 1965. Colorimetry of Total Phenolics with Phosphomolybdic-Phosphotungstic Acid Reagents. American Journal of Enology and Viticulture. 16: 144-158.

[26] Berbar, Y., Amara, M., Kerdjoudj, H. 2012. Effect of Adsorption of Polyethyleneimine on the Behaviour of Anion Exchange Resin. Procedia Engineering. 33: 126-133.

[27] Datta, C., Dutta, A., Dutta, D., Chaudhuri, S. 2011. Adsorption of Polyphenols from Ginger Rhizomes on An Anion Exchange Resin Amberlite IR-400-Study on Effect of $\mathrm{pH}$ and Temperature. Procedia Food Science. 1(Icef 11): 893-899.

[28] Kammerer, D. R., Saleh, Z. H., Carle, R., Stanley, R. A. 2007. Adsorptive Recovery of Phenolic Compounds from Apple Juice. European Food Research \& Technology. 224: 605613.

[29] Altiok, E., Baycin, D., Bayraktar, O., Ulku, S. 2008. Isolation of Polyphenols from the Extracts of Olive Leaves by Adsorption on Silk Fibroin. Separation and Purification Technology. 62: 342-348.

[30] Hatano, T., Edamatsu, R., Mori, A., Fujita, Y., Yasuhara, E. 1989. Effect of Interaction of Tannins with Co-Existing Substances. VI. Effects of Tannins and Related Polyphenols on Superoxide Anion Radical and on DPPH Radical. Chemical and Pharmaceutical Bulletin. 37: 20162021.

[31] Dogan, S., Salman, U. 2006. Partial Characterization of Lettuce (Lactuca Sativa L.) Polyphenol Oxidase. European Food Research and Technology. 226(1-2): 93103.

[32] Shahidi, F., Wanasundara, P. K. J. P. D. 1992. Phenolic Antioxidants. Critical Reviews in Food Science and Nutrition. 32: 67-103.

[33] Duh, P. D., Tu, Y. Y., \& Yen, G. C. 1999. Antioxidant Activity of Water Extract of Harng jyur (Chyrsanthemum morifolium Ramat). LebensmittelWissenschaft und-Technologie-Food Science and Technology. 32: 269-277.

[34] Dominique, R., Maria de Lourdes, D. N., Delgado, N., Daniel, S. 2009. Adsorption of Complex Phenolic Compounds on Active Charcoal: Adsorption Capacity and Isotherms. Chemical Engineering Journal. 148: 1-7.

[35] Borkowski, T., Szymusiak, H., Gliszcynska-Swiglo, A., Rietjens, I. M. C. M., Tyrakowska, B. 2005. Radical Scavenging Capacity of Wine Anthocyanins is Strongly $\mathrm{pH}$-Dependent. Journal of Agricultural and Food Chemistry. 53(14): 5526-5534.

[36] Altunkaya, A., Becker, E. M., Gokmen, V., Skibsted, L. H. 2009. Antioxidant Activity of Lettuce Extract (Lactuca sativa) and Synergism with Added Phenolic Antioxidants. Food Chemistry. 115(1): 163-168.

[37] Tan, P. W., Tan, C. P., Ho, C. W. 2011. Antioxidant Properties: Effects of Solid-To-Solvent Ratio on Antioxidant Compounds and Capacities of Pegaga (Centella asiatica). International Food Research Journal. 18(2): 557 562.

[38] Khoo, M. Z. 2009. Comparative Study on Polyphenol Antioxidant Activity of Misai Kucing (Orthosiphon stamineus) Crude Extract. Thesis. UCSI University, Malaysia.

[39] Balasundram, N., Sundram, K. and Samman, S. 2006. Phenolic Compounds in Plants and Agri-industrial By- 
products: Antioxidant Activity, Occurrence, and Potential Uses. Food Chemistry. 99: 191-203.

[40] Kähkönen, M. P., Hopia, A. I., Vuorela, H. J., Rauha, J.P., Pihlaja, K., Kujala, T. S., Heinonen, M. 1999. Antioxidant Activity of Plant Extracts containing Phenolic Compounds. Journal of Agricultural and Food Chemistry. 47(10): 39543962.
[41] Haslaniza, H., Saiful, I. Z., Wan, A. W. M. \& Mohamad, Y. M. Characterizing the Deacidification Adsorption Model of Organic Acids and Phenolic Compounds of Noni Extract using Weak Base Ion Exchanger. Journal of Chemistry. 2018: Article ID 6376929. 